\title{
Phytophthora Root and Crown Rot of Plum
}

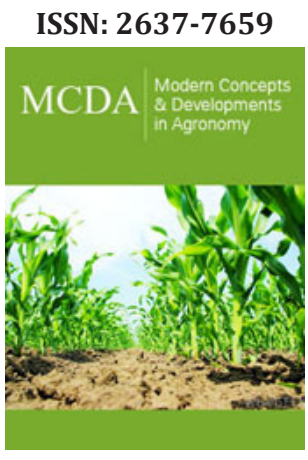

*Corresponding author: Vagelas IK, University of Thessaly, Department of Agriculture Crop Production and Rural Environment, Fytokou St., N. Ionia, GR38446 Magnesia, Greece

Submission: 酱 August 08, 2020

Published: 僵January 05, 2021

Volume 7 - Issue 5

How to cite this article: Vagelas IK. Phytophthora Root and Crown Rot of Plum. Mod Concep Dev Agrono. 7(5). MCDA. 000671. 2021. DOI: 10.31031/MCDA.2021.07.000671

Copyright@ Vagelas IK, This article is distributed under the terms of the Creative Commons Attribution 4.0 International License, which permits unrestricted use and redistribution provided that the original author and source are credited.

\section{Vagelas IK*}

University of Thessaly, Department of Agriculture Crop Production and Rural Environment, Fytokou St., N. Ionia, GR-38446 Magnesia, Greece

\section{Abstract}

In this study was investigated the Phytophthora spp., effects on plum trees in Skopelos island, Greece. Trees impacted by Phytophthora showed collar rot symptoms (below ground), crown rot and reddishbrown discoloration of the bark and poor growth with sparse, off-color foliage (above ground). Results showed that improve soil drainage techniques and application of fosetyl-Al when new leaves are hardening proved a good strategy to encourage

I. Healthy new root growth,

II. Reduced Phytophthora root and grown rot symptoms and

III. Increase plum fruits production.

Methodology-Results and Discussion
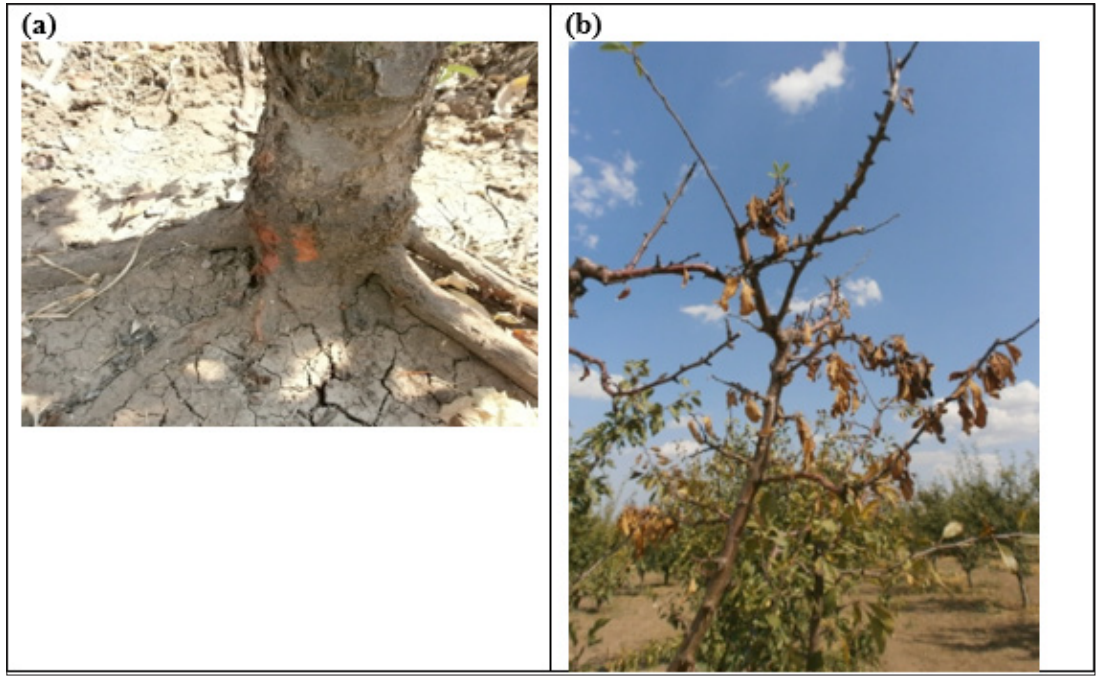

Figure 1:

a) Reddish-brown streaks or zones can be seen on the inner bark of infected plum tree.

b) Leaves of plum tree affected by Phytophthora.

Phytophthora spp. were isolated from necrotic root and tissues of decline and dead plum trees in 22 plum orchards in Skopelos, Greece. In details, a total of 152 samples of decline and dead plum trees were collected and analysed at Phytopathology Lab of the University of Thessaly, through 2012-13 and 2015-17 [1]. All decline trees attributed the following symptoms, crown and collar rot and reddish-brown discoloration of the bark (Figure 1a). Trees with crown symptoms show a gradual loss of vigor and decline of the top generally have a reduced number and size of leaves produced. The leaf color during the warm weather, late May and middle summer were observed to turn prematurely yellow, wilt, dry, and remain attached to the tree (Figure 1b). Trees with foliar symptoms usually were associated with loss of canopy, showed branch dieback symptoms and eventually ending in death of the stunted growth tree [2]. The most outstanding symptom of the loss of canopy and the real cause for death of the top of the tree is the slowly developing canker on the lower trunk near the ground line, the "crown" region of the tree (Figure 1a). These cankers extended from the crown of the root system to ground level and along the lateral roots. In a lot of cases (especially in 3-5 years 
old plum trees), the canker girdled the trunk and the bark within the canker was completely rotted and the outer wood discolored. In all cases Phytophthora spp. were isolated from all samples showed that Skopelos local cultivar or certain local rootstocks have no tolerance to Phytophthora root and grown rot disease. Improve soil drainage techniques (drill holes into smooth sections of the trunk or main roots) and application of fosetyl-Al $80 \%$ (WG) when new leaves are hardening proved a good strategy

I. To encourage healthy new root growth,

II. Reduced Phytophthora root symptoms and

III. Increase plum fruits production (Figure 2a\&2b).

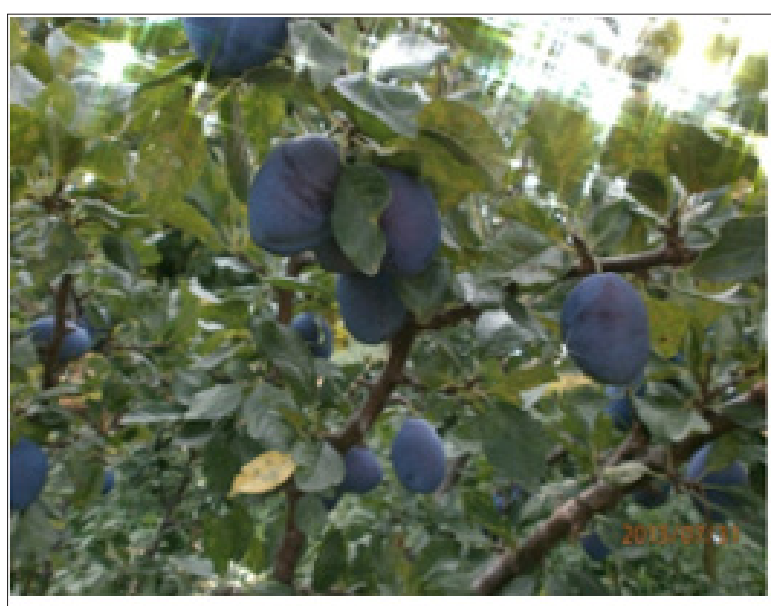

a

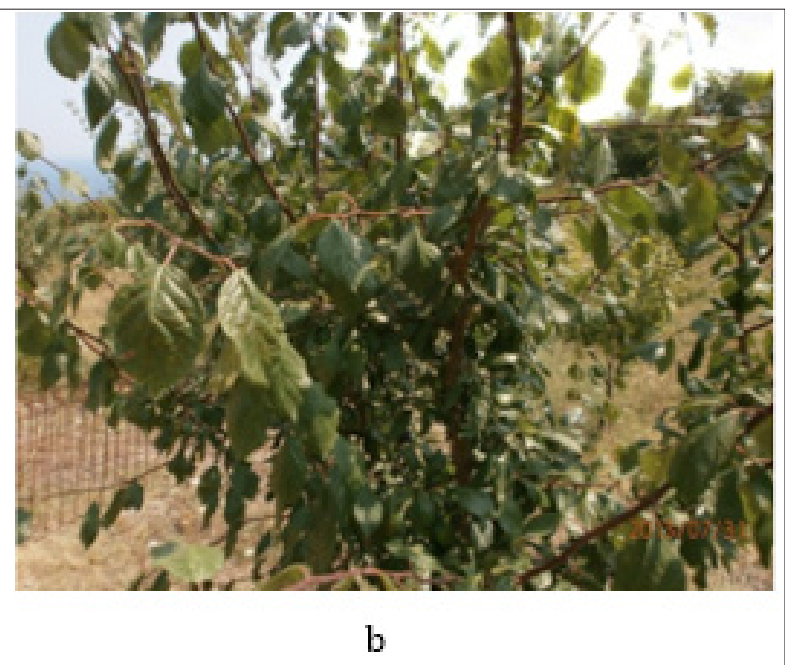

\section{Figure 2:}

a) Treated plum tree.

b) With fosetyl-Al (80\%) when new leaves are hardening compared to untreated plum tree.

\section{References}

1. http://ipm.ucanr.edu/PMG/r611100611.html

2. http://hdl.handle.net/1813/43116 